Ganesh, Kamala (2018): The Call of Home and Violence of Belonging: Diasporic Hinduism and Tamils in Exile. In: Elfriede Hermann and Antonie Fuhse (eds.): India Beyond India: Dilemmas of Belonging. Göttingen: Göttingen University Press (Göttingen Series in Social and Cultural Anthropology, 12), pp. 195-210. Doi: 10.17875/gup2020-1270

\title{
10 The Call of Home and Violence of Belonging: Diasporic Hinduism and Tamils in Exile
}

\author{
Kamala Ganesh
}

\section{Introduction}

To escape the trauma of violence and civil war, more than a million ethnic Tamils have emigrated from Sri Lanka since 1983. Today, they live in different pockets of the globe, and are interlinked through a powerful transnational network. As a diaspora, they are defined by a shared commitment to the cause of Tamil nationalism in Sri Lanka. The million-plus Tamils who have emigrated since 1983 constitute a distinct and influential niche within the four million strong Tamil diaspora. ${ }^{1}$ Indeed, the broader Tamil diaspora dating from pre-colonial times is composed of several historical and cultural layers, with varying inclinations towards assuming a Tamil ethnicity. In the pre-colonial period, mercantile traders and financiers like the Nattukkottai Chettiars spread throughout Southeast Asia, merging and mingling with local cultures. As their numbers increased during the colonial period, so too did the intricacy of their enterprises, and the community flourished. People and money circulated through well-honed networks between South India and Malaya, Burma, Straits settlements, Siam, Java, and Indo-China, enabling considerable business success (Kudaisya 2006: 60-61). Due to their itinerant modes of business, these emigrant communities did not develop a strong diasporic consciousness, with Tamil

\footnotetext{
1 Tamils across the globe number 70 million spread in 50 countries of the world of which 61 million are in Tamil Nadu, 5 million in Sri Lanka (Sivasupramaniam n.d.).
} 
functioning as the mother tongue rather than as the ethnicity. At the same time, for the Tamil-speaking indentured labor migrants in Malaya, Fiji, Mauritius, the Caribbean, and South Africa, Tamil ethnicity would became an integral element of diasporic self-assertion. For the most part, this assertion of identity was either a response to host country policies and politics, as was the case in Malaysia, or to the dynamics of interaction with other diasporic Indian communities, as was the case in South Africa. Post-independence and post-liberalization Tamil migration from India to the West and to English-speaking countries like Australia and Singapore was mostly composed of upper and middle caste, highly qualified, professionals. For these migrants, being Tamil was more casual and functional than based on deep ethnic identification. Today, for example, spoken Tamil is interlaced with English, with many second generation migrants not speaking Tamil at all. In contrast to these previous waves of emigration, the post-1983 Tamil diaspora from Sri Lanka, ${ }^{2}$ a language-based ethnicity has mutated into a powerful force expressed through the notion of biological species-hood, conveyed in the popular term Tamil Inam. Such an unusual evocation is not an assertion of citizenship rights in the adopted land, but rather invokes a politics of primordiality and belongingness to the homeland from which they were forcibly displaced.

For a language to take on the mantle of ethnicity is a complicated process: for it to become an ethnicity in the Indian context, a language has to coincide with region, and bridge caste and religious divides. In the past hundred years, Tamil ethnicity has shaped two powerful movements on the subcontinent: the Dravidian movement in the Tamil region of India, and the Tamil nationalist movement in Sri Lanka. The continuation and offshoot of the latter in the diasporic context is the focus of this chapter. The Dravidian movement, which arose in Madras Presidency in the 1930s, was based on the perception that the Tamil region, with its ancient language, robust literary tradition, and distinctive cultural ethos of two millennia, had been sidelined by Sanskritic and Aryan domination from North India and by local Tamil Brahmins. Tamils were seen by the Dravidian movement as naturally constituting a separate nation. Even the canon and practice of Hinduism had a distinct lineage and markedly regional features. ${ }^{3}$

\footnotetext{
${ }^{2}$ Henceforth in this article, the 'Tamil diaspora' refers only to Sri Lankan Tamil migrants, unless otherwise specified.

3 The Dravidianism and Tamil exceptionalism propagated by Periyar E.V. Ramaswamy Naicker has been the root of subsequent politics in Madras state (current day Tamil Nadu) (Geetha and Rajadurai 1998). While even lay observers have noticed the vast dilution of Tamil exceptionalism (Krishna 2015), it continues as an ideological undercurrent. Over the course of time and in the dynamics of democratic politics, the secessionist agenda has evaporated. For pragmatic electoral reasons, many compromises have been made in the translation of Dravidian politico-cultural ideology into practice. Yet the founding principles, the antiquity, distinctness and distinction of Tamil language and literature has remained on the Dravidian agenda. The campaign for the Indian government to recognise Tamil as a classical language, which was successful in 2010 , is a testimony to this (see for example Vasan 2004).
} 
Dating back to $19^{\text {th }}$ century colonial policy and orientalist invocations of the linguistic and cultural divide between Indo-Aryan Sinhalas and Dravidian Tamils, the Tamil nationalist movement in Sri Lanka has even deeper historical roots (for a concise history see Wilson 2000; for a detailed account see Kailasapathy 1985). The political manifestations of the Tamil nationalist movement in the mid-to-late $20^{\text {th }}$ century drew some inspiration from South Indian Dravidianism, but also developed unique features in response to ethnic tensions in Sri Lanka. The growth of militant and terrorist organizations like the Liberation Tigers of Tamil Eelam (LTTE), the mass exodus of Tamils seeking refuge and asylum in other countries, and these diasporic waves' sympathy for the Tamil cause gave the relationship with the homeland a special emotional color, with Tamil surpassing the stage of mere ethnicity into what can be called 'Tamilism.'

The very condition of diaspora-ness triggers a complex relationship with the homeland, a relationship sometimes anchored only in the imagination, to paraphrase Anderson (1998). Even when it remains only a mythic or rhetoric motif, and even if it does not actually happen, return remains an ever present focus; so much so that diasporas may support the cause of the homeland, whether defined territorially or emotively, through concrete actions such as support to the state and its programs. For example, the Indian diaspora in the USA famously bailed out their home country during the 1990 foreign exchange crisis. Indeed, as the Encyclopedia of the Indian Diaspora (Lal, Reeves and Rai 2006) notes, this event triggered a radical turn around in the Indian government's hitherto lukewarm attitude towards its diasporas. The recent growth in diasporic philanthropy and development aid is another example of involvement in homeland welfare without actual 'return' (Kapur 2010: 84-161). Sections of the Indian diaspora's support for the Khalistan and Hindutva exclusivist, separatist movements are two recent and problematic examples of diasporic identification with the 'homeland.' In both cases, "long-distance nationalism" as formulated by Anderson (1998) has been articulated in terms of religious identity. In contrast, for the transnational Tamil diaspora, violently exiled from Sri Lanka during and after the civil war, Tamil language and culture, rather than religion, has been critical to the politics of homeland nationalism. Nevertheless, in the articulation of Tamilness, a prominent space is occupied by religion, specifically by what can be called 'Tamil Hinduism.' The flourishing network of temples built by the Tamil diaspora accommodates and, at times, propagates such a political assertion of Tamilness. Likewise, the devotion to classical Carnatic music is inflected with Tamil Hinduism.

This chapter explores the nature of belongingness among the Tamil diaspora. It is based on fieldwork in Germany and Switzerland, but also contains reflections on the diaspora in Europe as a whole. With the dispersal of emigrants during and after the civil war, members of the same family often found themselves settling in different countries. Nevertheless, Tamils throughout Europe have maintained close kinship, business, cultural, and community ties and form a cohesive transnational community. Tamil temples, in a sense, constitute the face of Hinduism in Europe, for reasons that will become evident later. The temples maintain links with diasporic Hinduism 
at large, as well as with institutions and temples in South India, sourcing services and products, and seeking ideological collaboration and legitimation. Yet they have kept a distance from Hindutva, which focuses on the politicization of religion, and is specific to the Indian context. ${ }^{4}$

In this chapter, I also examine the Tamil diaspora's intense religiosity (based on Saivism) - a prominent component of Tamil devotionalism - which not only functions as a spiritual anchorage but also adds moral and ethical weight to the political engagements of Tamil nationalism. Despite being at the forefront of temple-centered Hinduism in Europe, this diaspora has no relationship to Hindutva. I also examine the role of classical music in promoting both Saiva devotionalism and Tamil nationalism. The incompatibility of Tamil Hinduism in the diaspora with Indian cultural nationalism illustrates the irreducibility of the many faceted diasporic Hinduism to Hindutva ideology. Like religious nationalism, linguistic ethnonationalism, even if it has valid claims to justice, can be violent, totalitarian and exclusive, as the examples of diasporic Tamils and diasporic Hindutva discussed in this chapter suggest. Against this background, and with its diverse expressions in the individual psyche, in the last section I explore the violence of belonging through the narrations of two Tamil women, one a music teacher in Münster, and the other a devout member of the religious community in Bonn. ${ }^{5}$ Before migrating to Germany, both suffered personally in the Sri Lankan civil war, yet their responses to the diasporic engagement with the homeland politics are in stark contrast to one another.

\section{On Belonging, Return and Violence}

Does belonging, in the domain of group or collective identity, even in its benign manifestations, inevitably entail exclusiveness and exclusions? And is it followed inevitably by a slide into violence? The homeland-diaspora relationship is one that has potential for illuminating the delicate line between passion and violence.

The existential situation of a migrant group forcibly separated from the homeland, yet emotionally attached to it, was seen by early scholars as critical to the development of a diasporic consciousness. Safran's (1991) article, which continues to be a reference point in diasporic studies, lists six necessary features of a diaspora, with five of these associated with the 'homeland': dispersal from the homeland; a collective memory or myth of 'home'; the idea of return; commitment to the homeland's wellbeing; and a continued relationship, be it personal or vicarious, to the homeland. Safran (1991: 83-84) concludes that even if emigration is voluntary, and individuals

\footnotetext{
${ }^{4}$ Hindutva, a form of Hindu nationalism is a political ideology as distinct from Hinduism as religion. It was elaborated upon by prominent Hindu right wing ideologue V.D. Savarkar, who it is believed inspired Gandhi's assassination. It seeks to establish the hegemony of Hindus and the Hindu way of life. 5 The names and some of the personal details of persons (informants) in this chapter have been changed slightly to protect their identity.
} 
or groups hold no plan to actually return, the diasporic consciousness rests on a real or imagined relationship with the homeland.

Later scholars have questioned whether all diasporas are so focused on a continuous connection to the homeland and a teleology of return. As Clifford (1994: 304) argues, exclusivist paradigms are difficult to maintain. Likewise, Cohen (2008: 6-8) argues against overemphasizing the homeland connection; the shared present may be more important than a common origin. The homeland relationship is, at the level of identity, about making a life in the host country, not about the real 'backhome.' In forging this identity, members of the diaspora seek to combat structural inequality and cultural unacceptance by asserting difference and claiming rights as citizens of the host country. Brah (1996) underlines the distinction between the 'homing desire,' a mythic place of desire in the diasporic imagination, and an actual desire to return. Some regional diasporas, despite being composed of people from different countries, share historic linkages as well as a rich high and popular material culture of consumption, with public arenas and economic channels for cooperation and communal enjoyment cutting across the national origins or religious beliefs of performers and participants (Werbner 2010: 76). The countries in the Indian subcontinent are a striking illustration of this point. Although members owe political allegiance to various homelands, the South Asian diaspora is an example of a 'complex diaspora' (ibid.) with a shared history and culture. Indeed, for double and triple diasporas (which have relocated from their first destination and may therefore have more than one homeland as a reference point), the concept of 'homeland' becomes even fuzzier.

Importantly, these arguments undermine the centrality given to the relationship with the homeland in the ideal-typical Jewish diaspora, which had initially been held up as a model in diaspora studies. In excluding a substantial segment of migration, especially voluntary migration for better opportunities in education or work, the classic definition of diaspora has been too narrow.

Nevertheless, there is a continuing case for discussing the specificities of forced migration as a special category of diaspora; this is not to portray forced diasporas as quintessential in some way, but rather to focus on the diasporas' collective work of memory, commemoration, and mourning, processes which lead to multifarious forms of moral and material connection with the homeland. As Tölölyan argues, a diaspora born of catastrophe inflicted on the collective suffers trauma, which in turn shapes much of its cultural production and political commitment. As such, it is helpful to distinguish such diasporas from a dispersion that is the consequence of individual and chain migration motivated by economic reasons; for in such communities, nostalgia may be strong, but commemoration and collective mourning are less prominent (Tölölyan 2007: 649).

Traumatic expulsions of entire communities for political reasons have created several 'stateless' diasporas, such as Tamils, Kurds and Palestinians, for whom the homeland is not only symbolic, but also a political rallying point (Sheffer 2003: 154-59). To them, the homeland remains relevant in a substantive way: return may 
not literally happen, yet re-turn - travel to the homeland, remittances, cultural exchange, political lobbying, and various contingent efforts to maintain other benign links with the homeland - does (Tölölyan 2007: 650). The experience of trauma, exile, and the relative economic and political security achieved in the new adopted land also triggers and enables a form of re-turn to the homeland through the financial and moral support and promotion of political violence.

This is indeed the case with the Tamil diaspora, which has two striking features: its extreme preoccupation with the issues of Tamil nationalism and justice back in Sri Lanka, and the harnessing of its own cultural capital to reinforce and propagate the Tamil cause through language, literature, art, and especially through religion.

\section{Re-Turn to the Homeland: Overseas Hindutva}

My fieldwork with Tamils exiled in Europe brought home to me how their religious fervor was suffused with devotion and piety anchored in the Tamil Saiva regional and cultural ethos. As both an insider and an observer in Tamil Nadu itself, this ethos was familiar to me, as there was hardly any difference in substance between the two, only minor stylistic differences. Yet Tamil Nadu as part of the Indian mainland has had a different relationship with political Hinduism than the Sri Lankan Tamil diaspora. In fact, there are signs of a turn towards Hindutva in Tamil Nadu (see for instance Krishna 2015). This turn is taking place despite the dominance of Dravidianism in Tamil Nadu's recent history and politics, which has made it one of the Indian states least amenable to Hindutva.

In recent decades, with new channels of direct contact and communication opening up between emigrants and the homeland, the role of diasporas in bolstering violent ethnonationalist and communal conflicts in the homeland have become both more intense and more visible. Anderson's thesis on long-distance nationalism (1998) is often invoked as an explanatory framework for this phenomenon. One oftcited example is the political right in India's (and its Hindutva ideology) powerful support amongst the large, politically articulate, and economically successful Hindu diasporas.

It is often assumed that diasporic Hinduism is deeply implicated in Hindutva, and that the relationship is embedded in the very structure of Hinduism, with its inherent hierarchies and othering mechanisms. Such a reductive equation of modes of belongingness to modes of communal politics is challenged by the chaotic multiplicity of diasporic Hinduism, both in its normative and performative dimensions. Indeed, the Tamil diaspora - both in Europe and elsewhere - challenges such reductive assumptions and raises piquant questions on the problems of conflating communalism with religion, on the violent dimensions of belongingness, and on the heterogeneities and contrasts within diasporic Hinduism. 


\section{Tamil Diaspora: Tamilness as Ideology and Strategy}

Though it is relatively young, a number of scholars have written about the Tamil diaspora. I have also drawn on my own fieldwork in Europe (Ganesh 2013, 2014; Ganesh and McDowell 2013). Some key features of the community are common across locations, with most fleeing Sri Lanka following the turbulent ethnic conflict, seeking refuge and asylum, especially after the devastating Colombo riots of 1983. The long and complex history of ethnic conflict between the Sinhala government, civil society, and Tamil civilians in Sri Lanka is well documented. With the emergence of the Liberation Tigers of Tamil Eelam (LTTE) as a key player in the early 1980s, the conflict developed into a full-scale civil war. ${ }^{6}$ Powerful LTTE networks abroad mobilized the diaspora's empathy for the Tamil cause, raising money for humanitarian and military purposes, and it is widely believed that the diaspora played a role in keeping the civil war going as long as it did. While the majority in the diaspora were sympathetic to the cause, they were also ambivalent about or opposed to the violence. ${ }^{7}$ Nevertheless, by exerting moral pressure, playing on guilt and threatening relatives back home, the LTTE drew diasporic Tamils into its violent Eelam (nationalist) politics (see for instance Wayland 2004). The pressure the LTTE was able to exert within the diaspora must be understood in the context of a history of discrimination and suffering in Sri Lanka, with the loss of lives and property, the trauma of displacement and asylum, and the struggle to rebuild life from scratch. As such, Vimalarajah and Cheran (2010: 7) argue that the diaspora's commitment to Tamil nationalism went and goes beyond specific organizations like the LTTE.

The longing for homeland, the mythical Eelam, as well as the physical home, property and relatives left behind in Sri Lanka, have arguably affected the terms of the diaspora's engagement with its host countries. Tamils in Europe have developed a reputation for being 'good immigrants' (which is obviously also related to the current dynamics of immigration policy); they are seen as hard-working, reliable and resilient immigrants willing to take up low-paying jobs that others do not want. Moreover, they have 'integrated' well into the education, employment, and health systems, but have largely remained socially aloof, confining their interactions to fellow ethnics (Ganesh 2014: 237). Now young adults, the second generation, have integrated better, excelling in higher education. Nevertheless, they too engage with homeland politics, albeit differently.

\footnotetext{
6 The civil war fought between the LTTE and the state military ran between 1983 and 2009. There were phases when the LTTE scored military victories in specific locations and, for a period, ran a parallel administration in those areas. Eventually the violent excesses of the LTTE led to an international campaign against it, and it was declared a terrorist organization. In 2009, it was defeated and decimated.

7 In my fieldwork in Europe over five years from 2009 onwards, I came across this sentiment frequently. Whether such views were expressed only in the aftermath of defeat, I cannot prove. But there are studies (e.g. Vimalarajah and Cheran 2010) that do point out to various nuances in the diaspora's relationship with LTTE.
} 
Diasporas everywhere are preoccupied with issues of cultural identity, with the mechanics and politics of survival and recognition in the host country often playing a primary role. For Tamils, this is intensified by the politics of the homeland. The mobilization of a purportedly unique Tamil identity has been a key strategy in ensuring, strengthening, and maintaining support from Sri Lankan Tamil diaspora in Tamil nationalist politics, ethnic conflict, and the civil war. These identity politics have meant that the highly religious Tamil diaspora has remained indifferent to the overtures of Hindutva's religio-cultural nationalism while making itself available to the political demands of Tamil linguistic ethno-nationalism. The result is an inwardlooking diaspora with an unparalleled mobilization of what is considered to be authentic Tamil religion and culture. This Tamilness is invoked through language, literature, arts, marriage and food choices, and modes of dress, worship and behavior. What one may call a distinct Tamil Hinduism - as practiced traditionally in Jaffna and Tamil Nadu, as well as in the diaspora - provides symbolic capital. Moreover, a vigorous system of weekend schools (attended by the majority of children) which teach Tamil language, literature, and history, as well as philosophical, musical, and cultural traditions intertwined with Tamil Hinduism socializes them to Tamil nationalist goals. Spread across multilingual Europe, the diaspora retains Tamil as the language of communication in newspapers, on TV channels and websites, and during community gatherings. Tamil 'culture' is also performed through classical music and dance which focus on Tamil devotional compositions and are conducted in Tamil schools, temples or private homes (Ganesh 2014: 238-41).

In what follows, I will discuss two powerful cultural channels for Tamil nationalist politics in some detail, namely temple-centered devotional Saivism, and the teaching and performance of Carnatic music.

\section{Tamil Hinduism and Temple Building}

The heightened religious consciousness of immigrants as a category has been noted by many scholars (see e.g. van der Veer 1994 and Williams 1988: 11). Regardless of denomination, an elaborate and intense expression and performance of religiosity both on an everyday level and in public ceremonies is a striking feature of the Tamil diaspora. ${ }^{8}$ Even Tamilness itself, the core ideology of the diaspora, is articulated in religious terms.

The majority of Tamils in Europe are Hindus. The theological base of Sri Lankan Hinduism is the same as the dominant Saiva discourse in Tamil Nadu, expressed through the worship of Siva, Murugan, Amman, and Devi. Inspired by the bhakti poetry of the medieval Tamil saints, it draws on the non-Brahmin traditions of Saiva Siddhantam and Vira Saivam (Subramaniyam 1994). Saiva Siddhantam, one of the

\footnotetext{
${ }^{8}$ Using quantitative data, Baumann and Salentin (2006: 306-310) have demonstrated Tamils' high levels of self-reported religiosity.
} 
three major Saiva streams, derives its metaphysics not from Vedanta but from the Siva Agama and Siva Stotras. A cohesive, non-Vedic Tamil philosophy, metaphysics, and temple-based liturgy has been consolidated over more than a millennium, creating a powerful and regionally rooted devotional Hinduism. It is an allied, parallel tradition to Vedic Hinduism, with points of convergence and divergence. With its distinct identity, the Tamil Hindu tradition arguably provided fertile soil for the later political and social developments of Dravidianism. While in Tamil Nadu, Vaishnavism also flourished, in Sri Lanka, Saivism has held almost exclusive sway. Over the centuries, Vaishnava deities have also become (somewhat) accommodated within the Saiva tradition. Saivism has also been in amiable interaction with Catholicism, in the sense of devotees participating in each others' festivals. Diasporic Tamils have largely followed the pattern of Saiva worship in Sri Lanka, although interaction with pan-Hindu traditions and neo-Hindu sects and cults have made it adaptive, syncretic, and inclusive (Schalk 2004).

The Tamil diaspora in Europe not only worships in the home, but has also built a number of temples. Temples play an important role, acting as a rallying point in mobilizing and intensifying Tamil identity around politico-cultural issues. Indeed, in Germany alone, nearly 40 temples have been built, whereas Indians (who have a much longer presence there) have built only one temple - the Sri Ganesha Hindu Tempel, which is still under construction in Berlin. As such, Tamil temples are the face of diasporic Hinduism in Europe. Indeed, the efflorescence of temple-based Hinduism in Europe is directly attributable to Sri Lankan Tamil religiosity, which in turn can be seen as an existential as well as political response to ethnic conflict, war, loss and exile at 'home' (Ganesh and McDowell 2013; Ganesh 2014).

The LTTE was careful to remain neutral towards religion: Tamilness was constructed as binding people across and beyond religion. Yet the LTTE utilized religious channels, especially the temple as a forum for propaganda and mobilization. After all, the two major ethnic groups in Sri Lanka were largely polarized along religious lines: Tamil Hinduism and Sinhala Buddhism, with the latter playing a significant role in the conflict. Many temples maintain some concrete connection with homeland politics: several are known to be linked directly, as patrons or managing committee members, with LTTE sympathizers; some put up posters for National Heroes Day in remembrance of soldiers killed in war; and some even hold memorial functions in the temple (a contentious issue that has split temple committees). Swaminatha Kurukkal, a priest at the Durga temple on the outskirts of Zurich, told me that during the temple festival, donations for the war were collected outside the premises from the assembled devotees. He did not mind when special pujas were asked to be held in his temple for individuals who became 'martyrs' in the war, for in God's eyes, all who died were equally deserving of his grace. While he too was a sympathizer, he refused to hold a memorial function to collectively mourn the 'martyrs,' saying that it was an abuse of the temple's sanctity. This stance was not popular, and cost him significant patronage. Driving toward Zurich one morning in May 2009, at the height of the war, he heard on Tamil radio that LTTE chief Prabhakaran had 
been killed. "Though I had grown to abhor the violence that he had unleashed," he said, "at that moment I closed my eyes and shed tears for him and prayed for his soul. After all, he had brought the plight of the Tamils in Sri Lanka to the attention of the world."

The transnational character of this diaspora extends to its religious life too. For example, temples in Germany are closely connected to those elsewhere in Europe. Priests circulate and participate in special festivals elsewhere, when large contingents of ritual specialists are needed. They also switch locations, taking up new assignments, while devotees undertake pilgrimages to the powerful temples across Europe. Temples are thus bound in a transnational network closely allied to the transnational community itself, whose character has been shaped by ethnic nationalism and which in turn, as Wayland (2004: 425) demonstrates, has shaped the course of the civil war. So it would not be off the mark to argue that temple-centered Saiva Tamil Hinduism has played a role in the continuation of the civil war.

\section{Towards a Tamil Saiva music?}

A striking feature of the Tamil Diaspora's engagement with art and culture is its patronage of South Indian classical Carnatic music. This is remarkable because, both in South India and in the Indian diaspora at large, Carnatic music is an elite pursuit. Even though it is a creative source for a vast range of folk and popular musical genres, as a style in itself Carnatic is a niche genre, with few individuals learning, pursuing, or performing it. Before the reforms of the early $20^{\text {th }}$ century, Carnatic music and Bharatanatyam dance had been patronized by the temple and court, and were the hereditary preserve of traditional Devadasi communities. After the reforms, Carnatic music became the domain of a different, primarily Brahmin, elite. Prior to reform, the dominant languages of the compositions had been Telugu and Sanskrit. In its home in the Tamil speaking regions, these factors added to Carnatic music's aura of being difficult to learn, 'not for everyone,' and requiring long training. Even the move in the 1940s, spearheaded by the influential community leader and philanthropist Annamalai Chettiar, to propagate Tamil Isai - Carnatic music based compositions in Tamil - did not radically enhance the accessibility and popularity of the form. Terada (2008) documents the initial hostility to Tamil Isai from influential institutional centers like the Music Academy. Eventually, both sides retreated from their extreme positions, and compositions in Tamil became included in mainstream concerts. Still, the style, its teaching, and performative components arguably remain heavily influenced by Brahmanical culture (Krishna 2015).

Barring the small group of traditional priests who officiate at the temples, the Sri Lankan Tamil diaspora is for the most part not Brahmin. Rather, the diaspora is composed of various castes, including the high-caste Vellalas, and a number of middle- and low-ranking castes, and Dalits. Indeed, due in part to the unifying power of the Tamil nationalist movement, the Tamil diaspora is not a highly caste-conscious 
community. In practically all the towns where Tamils live, individual teachers provide lessons in Carnatic music classes, either at home or in institutional settings. Young girls and boys are encouraged, even compelled, by their families and communities to attend. In the courses, emphasis is laid on teaching compositions in Tamil, and more so, on devotional compositions in the name of Siva, Murugan, and Devi - all deities of the Saiva pantheon. A place to perform these songs is offered in the Saiva temples, where devotees sing Tamil devotional songs as part of liturgical ceremonies. As such, classical music teaching focuses on religious and devotional content, and discourages abstraction and improvisation.

The emphasis on classical music and dance in the diaspora traces back to Jaffna's cultural heritage and literary and artistic activities. Prior to the violent conflicts, members of the diaspora had maintained strong links with the classical arts scene in Tamil Nadu. Music teachers in the diaspora had usually trained at the Ramanathan Academy of Fine Arts at the University of Jaffna, and some had undergone training in Chennai in the Adyar Music College or the Kalakshetra of music and dance. Senior musicians like Sattur Subramanian, Maharajapuram Santhanam and others from Chennai used to give performances in Jaffna. Culturally Jaffna and Chennai were in close interaction for a very long time, until the civil war disturbed the relationship. The links with both Jaffna and Chennai continue in the diaspora, but the emphasis is no longer on acquiring professional skills, and rather on maintaining links with cultural roots and community identity.

\section{Belonging and Violence: Two responses}

Miriam George's work (2009: 112-115) on psychological distress among Tamil refugees shows how they display a resilience to cope through self-healing, adopting perspectives that allow them to find meaning in their suffering. The sagas of fear, loss and sorrow that the refugees narrate are surely related to the displays of extreme piety during temple worship. Indeed, it is clear that healing and psychic reintegration into a stable personality spectrum are powerful needs that the temples meet.

The role of temples in healing was especially evident in the activities of Vimalakka, a deeply religious community leader in Bonn. A devotee engaged in temple-centered worship and activities, Vimalakka was also an activist for Tamil nationalism. "Without these temples here in this foreign land, we would have gone mad," she told me, referring to the struggle to survive and succeed in the new country. Her life story illuminates the role of women in war and peace, and more disquietingly, in supporting ethnic conflict. Vimalakka's childhood and young adulthood in Jaffna were steeped in the mythological lore, ritual and philanthropic practices of the Saiva Siddhanta sect. Her faith enabled her to negotiate heavy family responsibilities with fortitude, and imbued her life of personal sacrifice with meaning. Supporting extended family, feeding the poor, and performing rituals gave a fullness and grace to her life that her work at a textile mill could not. Following the unspeakable horrors of the 1983 riots, 
in which Vimalakka lost close relatives and her home and livelihood were destroyed, she fled to Germany. Starting from scratch, first as an illegal immigrant, then by working as domestic help, school cleaner, kitchen assistant, and in other low paying jobs, she slowly built a stable life for herself and her extended family. Throughout, she remained anchored in the religious beliefs and ritual practices of the Saiva canon. Today, she is a pillar of the community in its temple building and philanthropic activities. This role has given her the strength to move on and leave the horrific past behind.

In Germany, Vimalakka has continued to provide food, shelter and succor to her family and friends, and her circle has expanded to include all Tamil migrants, including nationalists, militants, and terrorists. As we passed an acquaintance in the train station, she waved to him and told me that he had remained an active 'Tiger' until the end of the war; when the wife of a family friend died, she came back from the funeral and reported to me how many 'Tigers' had attended. Indeed, Vimalakka herself actively participated in the Tamil diaspora's mobilization of support for the war, and her husband, a political activist, linked to the Transnational Government of Tamil Eelam (TGTE). ${ }^{9}$ Having always led a simple, pious life, she became increasingly politicized - a supporter of the LTTE who subscribed to its chauvinism, justifying its violent methods as a response to the cruelty and injustice meted out by the Sinhala army and government. In doing so, Vimalakka embodies the link between culture, gender, and violence and the way women become mobilized as participants and agents in identity-building. When victims of violence support retaliatory violence, how do we begin to understand it without contextualizing their perception (and facts) of historical wrongs?

Veni, a music teacher in Münster, responded to trauma in the opposite way. Throughout my conversations with her, she was consistently critical of the LTTE's political style, and especially its attempts to mobilize support for the war. She confronted LTTE supporters whenever they interfered with her work. She too had experienced the trauma of the ethnic conflict and civil war in Sri Lanka. Her family was connected to some of the Tamil nationalist parties, but she abhorred the violent methods of the LTTE. Not restricting her stories to those of the Sinhala army, she also recounted atrocities perpetrated by the LTTE - how young men and women were forcibly drafted into the organization, how they were trained to kill their own kin who might support other Tamil organizations, and how they hunted out suspected informers and killed them and destroyed their properties. Her own mother and brothers had to face brutality from the LTTE and had barely escaped being shot. Here in Germany too, the LTTE had extorted money from Tamils, ostensibly for the rehabilitation of children orphaned in the war, but in reality to fund their violent activities and to buy arms.

\footnotetext{
9 The TGTE is a Tamil Diaspora organization which considers itself a government in exile and is devoted to keeping the idea of a separate state of Eelam for Tamils. Its numerous activities and campaigns can be followed on http://www.tgte-us.org.
} 
Trained in Jaffna and Chennai, Veni teaches music to different groups of students in her home. Predominantly girls, the students go from five years old into their teens. During the evenings, parents coming in to drop and pick up children spend some time chatting with each other, exchanging community news and gossip.

Tamil compositions make up the majority of the lessons. Students also learn songs in other languages, such as Sanskrit and Telugu, and songs in praise of non Saiva gods; Veni herself is not an exclusive Saiva worshipper, having been influenced by her father's deep faith in Vaishnavism. Her students are trained to take examinations from the Academy of Fine Arts in London. The committee members/teachers of the institution, several of whom are Indian teachers based in London, make annual visits and evaluate the student performances and award certificates and diplomas.

Like other teachers in Germany, Veni's students perform a concert during the annual Navaratri festival. These performances are typically a 'Vani Vizha,' a celebration in honor of Saraswati, the presiding deity of the arts. The concert becomes a community occasion to parade her students' cultural accomplishments and also becomes an opportunity to perform and display their cultural belonging.

At the Vani Vizha in 2010, the proceedings started a good hour later than announced, with people trickling in slowly. By the time the show started, the hall was overflowing, with over 300 people in the audience. In public and work life in Germany, Tamils observe strict norms of punctuality. But here, the pace of the function was leisurely, the mood festive - one of community bonding. The formal inauguration was performed by the priest of the Mariamman temple, who invoked the blessings of the goddess Saraswati. To create an ambience of religious devotion, the hall and the stage were decorated with flowers and icons of various deities. The accompanying percussionist on the mridangam was Kausikan, a young man, born and brought up in Germany, an engineer by profession, pursuing music as a serious hobby. His mother had learnt music at the Ramanathan Academy in Sri Lanka. Like many other serious musicians in the diaspora, he had learnt Carnatic vocals and the mridangam from senior Chennai musicians during visits to India, while they were touring in Germany, and later through Skype lessons. Kausikan was also well-informed about the current Carnatic music scenario, the prominent musicians, their styles and strengths, their abilities and where they were performing. Despite the students and musicians associated with Veni being fiercely loyal to her, they did not all share her approach.

For Veni, Carnatic music was not exclusivist, rather it was a medium for a broad, eclectic Hinduism. She had an open and flexible approach to her music, her religion, and her nationalism. When I met Veni again in 2013, she said she had stopped holding Vani Vizha. The previous year, members of the community had threatened her because they found the style of music she taught and the function itself not sufficiently Saiva Tamil nationalist. Veni was disgusted more than frightened by their threats, and decided to stop the concerts rather than cave in to their demands. 


\section{Conclusion}

These two examples of Vimalakka and Veni have been consciously invoked to represent opposite ends of the spectrum of Tamilist belongingness that fuels the identity of this diaspora. The widespread opinion that this diaspora entirely caved in to coercive pressure from the LTTE and contributed to the continuation of the civil war is not borne out even in the case of Vimalakka. Even though an LTTE sympathizer, she arrived at this position through her own experience of war, loss and migration, and has exercised considerable agency in rebuilding her life in Germany, creating a sense of community and reinventing the temple traditions of Sri Lanka in the new environment. In the case of Veni, an abhorrence of violence and a desire for more inclusive, universal values is prominent.

Such examples show us that while the Tamil Diaspora has been united in its quest for justice in Sri Lanka, there are internal differences and debates on the ways to achieve it. A community in toto cannot be slotted as supporting militancy and terrorists. Nor can a religion like Hinduism be equated with political forms like Hindutva. Diasporic Tamils in exile stand as a testimony to the difficulties of assuming homogenous approaches to issues of belonging.

\section{References}

Anderson, Benedict. 1998. "Long-Distance Nationalism.” In The Spectre of Comparisons: Nationalism, Southeast Asia, and the World, 58-74. London: Verso.

Baumann, Martin, and Kurt Salentin. 2006. "Migrant Religiousness and Social Incorporation: Tamil Hindus from Sri Lanka in Germany." Journal of Contemporary Religion 21 (3): 297-323. doi:10.1080/13537900600925958.

Brah, Avtar. 1996. Cartographies of Diaspora: Contesting Identities. London: Routledge.

Clifford, James. 1994. “Diasporas.” In "Further Inflections: Toward Ethnographies of the Future." Special issue, Cultural Anthropology 9 (3): 302-38.

Cohen, Robin. 2008. Global Diasporas: An Introduction. 2. ed. London: Routledge. Ganesh, Kamala. 2013. "No Shri Ram in Lanka: Hinduism, Hindutva and Diasporic Tamils in Exile." 21st Smt. Nabadurga Banerji Endowment Lecture, 3.3.2011. Journal of the Asiatic Society of Mumbai 85: 13-18.

—_ 2014. "From Sanskrit Classicism to Tamil Devotion: Shifting Images of Hinduism in Germany." In Migration and Religion in Europe: Comparative Perspectives on South Asian Experiences, edited by Ester Gallo, 233-48. Burlington: Ashgate.

Ganesh, Kamala, and Christopher McDowell. 2013. "Switzerland.” In The Encyclopedia of Sri Lankan Diaspora, edited by Peter Reeves, Rajesh Rai, and Hema Kiruppalini, 137-44. Singapore: Editions Didier Millet in Association with the National University of Singapore. 
Geetha, V., and S. V. Rajadurai. 1998. Towards a Non-Brahmin Millennium: From Iyothee Thass to Periyar. Calcutta: Samya.

George, Miriam. 2009. "Sri Lankan Tamil Diaspora: Contextualising pre-migration and post migration traumatic events and psychological distress." PhD dissertation, Faculty of Social Work, University of Toronto. Accessed June 04, 2012. https://tspace.library.utoronto.ca/bitstream/1807/19270/1/Miriam_George_ M_200911_PhD_Thesis.pdf.pdf.

Kailasapathy, K. 1985. "Cultural and Linguistic Consciousness of the Tamil Community." In Ethnicity and Social Change in Sri Lanka: Papers Presented at a Seminar Organised by the Social Scientists Association, December 1979, 161-74. Colombo: Social Scientists' Association.

Kapur, Devesh. 2010. Diaspora, Development, and Democracy: The Domestic Impact of International Migration from India. New Delhi: Oxford University Press.

Krishna, T. M. 2015. "Dravidian-Hindutva Axis in Tamil Nadu: The Slow Death of the Periyar Atheist." http://www.openthemagazine.com/article/open-essay/ dravidian-hindutva-axis-in-tamil-nadu-the-slow-death-of-the-periyar-atheist. Accessed November 13, 2015.

Kudaisya, Medha. 2006. "Trading Networks in Southeast Asia." In The Encyclopedia of the Indian Diaspora, edited by Brij V. Lal, Peter Reeves, and Rajesh Rai, 59-66. Singapore: Editions Didier Millet.

Lal, Brij V., Peter Reeves, and Rajesh Rai, eds. 2006. The Encyclopedia of the Indian Diaspora. Singapore: Editions Didier Millet.

Safran, William. 1991. "Diasporas in Modern Societies: Myths of Homeland and Return.” Diaspora 1 (1): 83-99. doi:10.1353/dsp.1991.0004.

Schalk, Peter. 2004. God as a Remover of Obstacles: A Study of Caiva Soteriology Among İlam Tamil Refugees in Stockholm, Sweden. Uppsala: Acta Universitatis Upsaliensis.

Sheffer, Gabriel. 2003. Diaspora Politics: At Home Abroad. Cambridge: Cambridge University Press.

Sivasupramaniam, V. n.d. "History of the Tamil Diaspora." Accessed May 22, 2010. http://murugan.org/research/sivasupramaniam.htm.

Subramaniyam, E. 1994. The Philosophy and Practice of Saivism. London: Highgate Murugan Temple.

Terada, Yoshitaka. 2008. "Tamil Isai as a Challenge to Brahmanical Music Culture in South India." In Music and Society in South Asia: Perspectives from Japan, edited by Yoshitaka Terada, 203-26. Osaka: National Museum of Ethnology.

Tölölyan, Khachig. 2007. "The Contemporary Discourse of Diaspora Studies." Comparative Studies of South Asia, Africa and the Middle East 27 (3): 647-55. doi:10.1215/1089201x-2007-040.

van der Veer, Peter. 1994. Religious Nationalism: Hindus and Muslims in India.

Berkeley: University of California Press. 
Vasan, S. S. 2004. "The classical status of Tamil.” The Hindu Online, June 9. Accessed November 13, 2015. http://www.thehindu.com/2004/06/09/ stories/2004060903251500.htm.

Vimalarajah, Luxshi, and R. Cheran. 2010. "Empowering Diasporas: The Dynamics of Post-War Transnational Tamil Diaspora.” Berghof Occasional Paper 31, Berlin: Berghof Conflict Research. Accessed November 15, 2017. http://www. berghof-foundation.org/fileadmin/redaktion/Publications/Papers/Occasional_ Papers/boc31eBPS.pdf.

Wayland, Sarah. 2004. "Ethnonationalist Networks and Transnational Opportunities: The Sri Lankan Tamil Diaspora." Review of International Studies 30 (3): 405-26. doi:10.1017/S0260210504006138.

Werbner, Pnina. 2010. "Complex Diasporas." In Diasporas: Concepts, Intersections, Identities, edited by Kim Knott and Seán MacLoughlin, 74-77. London, New York: Zed Books.

Williams, Raymond B. 1988. Religions of Immigrants from India and Pakistan: New Threads in the American Tapestry. Cambridge: Cambridge University Press.

Wilson, Alfred J. 2000. Sri Lankan Tamil Nationalism: Its Origins and Development in the Nineteenth and Twentieth Centuries. Vancouver: University of British Columbia Press. 